\title{
The Development Of Ict-Based Levelling Reading Books For Improving English Vocabulary For Inclusive Primary Students
}

\author{
Ulhaq Zuhdi, Budiyanto \\ Universitas Negeri Surabaya \\ Surabaya, Indonesia \\ ulhaqzuhdi@unesa.ac.id
}

\begin{abstract}
The results of the research on the development of ICT-based levelling reading books aim to provide benefits for all inclusive primary students in grade 1 in Indonesia. The results of this study are expected to contribute to the improvement of their vocabulary which will be very useful knowledge for those facing global competition in Indonesia. The stages in this study include, 1) the preparation phase including clarification of material, designing the content of teaching materials based on the competency standards of each component. Then, 2) the implementation phase, which is compiling ICT-based levelling materials to completion, setting up the copy in the form of software can be a CD or FD, 3) the feasibility test phase, which is limited in its results evaluated by 2 experts from academics by English and media experts, 4) limited testing at SD Lab UNESA, 5) revision of ICT-based levelling Books from several aspects of the study.
\end{abstract}

Keywords-ICT; levelling reading book; english vocabulary.

\section{INTRODUCTION}

English as an international language and the language of the United Nations in the world has shown its urgency as the language of international communication. This makes almost all schools from the most basic levels to prepare students to master English. The earlier students are prepared better the development of their foreign language skills. This is because the brain of children in elementary school is classified as Golden Age in absorbing any lesson, especially foreign languages. The earlier the child learns a foreign language, the better his ability will be. As a fact, a child who has learned English from an early age will get the main basic skills and better listening and speaking which can even be close to native likes rather than adults.

The rapid growth of ICT (Information and Communication Technologies) has challenged the way of thinking of a teacher and lecturer to change the picture of education globally. As a recent result, it is seen that ICT has developed rapidly and has changed the educational environment.

The development of education is in line with the development of the era that everything has turned into globalization. Traditional learning from teacher to student directly only reduces the knowledge of the teacher to the student. This method is often characterized by material that has been set, given a time limit, assessment and criterion of criteria provided by the teacher. Research has proven that using ICT (Informational and Communication Technology) changes the paradigm of both content and teaching that becomes the core of the teaching in $21^{\text {st }}$ century .

The rapid development of ICT has made a revolution in learning. Technological innovations in education have led to new methods and media in teaching and learning. Teachers and students have now started a new era of challenges of the new learning environment, namely IT (Information Technology) that can be accessed through the gadget. It can be easier for teachers to understand about ICT and to teach through ICT

ICT is used as device for students to find tools for learning to find problems and to provide solutions. ICT provides easier knowledge acquisition and concepts in some lessons which become easier for teacher when giving assignments to students by using ICT. ICT has provided several creative solutions to improve learning. For example, for reading skill, e-books are usually used for reading aloud activities. This will enhance students' independence since they are able to access the information either by his gadget or by other devices.

Through ICT, students will learn more than what the instructor teaches. The students will be more active in learning. Unlike the traditional learning method, it is no need in this new learning method to use learning devices such as syllabi, lesson plans, and etc. Students can repeat the easy or difficult lesson whenever they like. The common problem found in conventional learning is that if there is no teacher, students' motivation decreases. On the other hand, by using ICT, there will be no reduction in motivation because the gadget can be used whenever students want. Using ICT does not require a specific location such as school; otherwise, it can be accessed wherever they want.

From the description above, the problem was formulated that would be solved in the development of this material which is "How to develop ICT-based levelling reading books to improve English vocabulary for inclusive elementary students in grade 1?" 
The aim of this study is to describe the development of ICT-based levelling reading books to improve the vocabulary of inclusive elementary students in grade 1 .

The results of the research on the development ICT-based levelling reading books are only limited to the mastery of SD Lab School UNESA inclusive elementary students in grade 1.

\section{LITERATURE REVIEW}

\section{A. Levelling Reading Books}

Levelling books are reading books arranged based on the level of students' reading ability: Level A is the simplest, up to level $\mathrm{F}$ which is the most complex (There are 6 levels). Participants practiced teaching the strategy in training [1]. The goal of levelling reading books is that all Indonesian citizens, especially children in school, to love reading and writing. It encourages children to be able to access information, understand the information he reads, and can use the information for useful things. The levelling reading books are divided into six levels of difficulty, ranging from the simple one for children who have just learned to read, to the higher level of difficulty for children who have already read fluently. Each level is marked by different colours of the books covers. Therefore, it is called levelling reading books because in reading, children will be adjusted to their abilities.

After participants understood the students' reading skills, student were grouped based on the books' level which were appropriate to the level of student's reading ability, the determination of reading strategies, and the development of student reading; Participants were invited to arrange programs in class/school and made a reading schedule for one semester as a whole. It is most concerned that this program will be a routine school program that is not included in school's regular schedule, but more on to support reading program which is required by the curriculum [1]. In Indonesia there is no levelling reading book for English in elementary level. With the existence of levelling reading books in inclusive elementary school, it is expected to improve vocabulary skills of elementary students and to possibly boost the ability to read and write in English automatically.

\section{B. Definition of ICT (Information and Communication Technology)}

The development of human civilization is in accordance with the development of ways of delivering information, which is known as the ICT (Information and Communication Technology). At first, Information Technology was developed by humans in prehistoric times and functioned as a system for the introduction of forms that they knew, the description of the information they got on the walls of the cave about hunting animals. Until now, information technology has been continuing to develop, but its delivery and form are more modern.

According to Reference [2], information technology is a mean and infrastructure (hardware, software, use ware) systems and methods for obtaining, sending, processing, interpreting, storing, organizing, and using data meaningfully. The same thing is also stated by Reference [3] that information technology is defined as computer-based science with its rapid development. Reference [4] explains that information technology is a technology used to process data.

The process includes processing, obtaining, compiling, storing, and manipulating data in various ways to produce qualified information, which is relevant, accurate and on time. According to McKeown in Reference [5], information technology refers to all forms of technology used to create, store, change, and use information in all its forms. Another theory is also explained by Williams in reference [5] that information technology is a general form that describes every technology that helps to produce, manipulate, store, communicate, and/ or convey information. Another supporting theory according to Behan and Holme in reference [6] states that information and communication technology is anything that supports recording, storing, processing, obtaining, transmitting / receiving and receiving information

Based on the opinions of the experts above, it can be concluded that information technology is a technology in the form of hardware, software, and useware that is used to obtain, transmit, process, interpret, store, organize, and use data meaningfully to obtain qualified information.

\section{Advantages of the Use of Information Technology}

According to reference [2], in general, there are three advantages of using information technology or computer and internet as the instructional media for education and learning. First, computer can be used to learn objects. Second, information technology facilitates learning in accordance with the curriculum that is applied in schools. For example, Pustekkom, the Ministry of National Education has developed an interactive multimedia $\mathrm{CD}$ program for subjects.

This opinion was also reinforced by Heinich in reference [2], ICT is all forms of use or use of computers and the internet for learning. Information technology can be utilized such as this following: 1) Tutorial, is a program that is delivered in a tutorial through a concept that is presented with text, images, and graphics; 2) Drill and practice, which is aimed to train students so that they have skills to strengthen the authority of a concept. This program usually provides a series of questions; 3) Simulation, this format aims to simulate an event that has occurred or not and is usually associated with a risk, such as a plane going to crash, catastrophe and so on; 4) Experiments, this format is similar to the simulation format, but is aimed more at experimental activities, such as practicum activities in the science, biology or chemistry laboratories; 5) Games, which refers to the learning process and with this formatted multimedia program, are expected to include some plays in studying activity.

From the various opinions above, it can be concluded that the benefits of ICT are as follows: first, ICT as a source that can be used for information sources and to find information that will be needed. Second, ICT as a medium is a tool that facilitates the delivery of information so that it can be received and understood easily. Third, ICT is as a developer of learning skills which is applicable for curriculum. 
Many researchers argue that new learning method by ICT in teaching and learning is crucial to provide opportunities for learning in today's electronic era. With ICT learning, the ability of students is prepared to deal with the times development based on a proper understanding. The use of ICT can help students to become more knowledgeable, can reduce the amount of direct teaching given to them and provide opportunities for teachers in those with special needs.

ICT plays an important role in improving student skills, motivation and knowledge of students. ICT can be used to present information to students and can help them complete learning tasks. A very important aspect of ICT is to convey abstract concepts, which is very useful in fulfilling student learning outcomes.

\section{Use of ICT in the education field}

In teaching in the 21 st century, students need optimized learning. Traditional learning has produced several differences on what is taught in school and what is desired in the world of work. ICT has given students to be independent learners and critical thinker. A teacher will develop a strategy that will enhance deep learning and change the learning environment to a student-based learning. The impact of ICT can be obtained from various ways to meet the needs of students different from traditional teaching which requires one way only (information obtained from a teacher to students). ICT offers different models in teaching and learning.

The difference in the use of ICT can be visualized as: CAI (Computer Assisted Instruction), Web Learning, Computer Classes, On Line Training, Distance Learning, Visualization Software, E Learning, Virtual Learning, Digital Learning and so on. All of these techniques are used in ICT which transform into a new paradigm that nowadays teacher plays a role as a facilitator. The presence of ICT affects the teachers to change their teaching practices. Research has proven that the use of different approaches offered by ICT will change the learning environment to student-centered learning and enhance deep learning taken from some examples of several approaches that use ICT as a teaching and learning process.

\section{METHOD}

This research is a development research. According to Reference [7], it simplifies 10 steps in developing mini-courses into 5 main steps, namely (1) analyzing the products to be developed, (2) developing the initial product, (3) expert validation and revision, (4) small-scale field trials and product revisions and (5) large-scale field trials and final products.

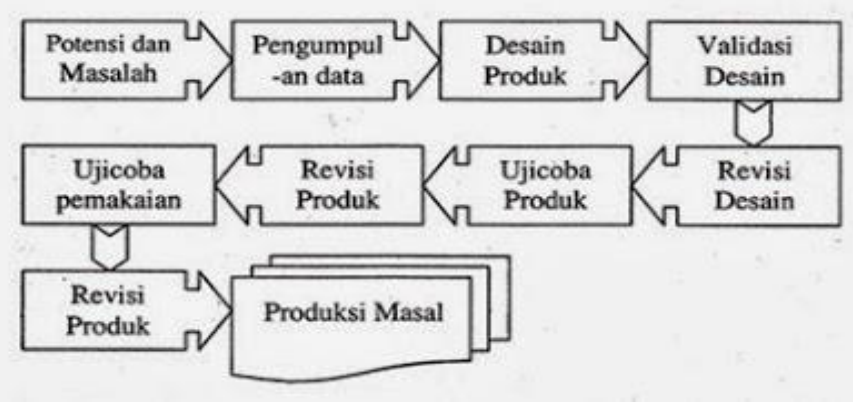

Fig. 1. Steps to Use the R \& D Method [reference 8]
The stages in this study included, 1) the preparation phase including clarification of material and designing the content of teaching materials based on the competency standards of each component. 2) The implementation phase consisted of compiling ICT-based levelling materials to completion and setting up the copy in the form of software can be a CD or FD, 3) the feasibility test phase, which was limited in its results evaluated by two experts from academics by English lecturers and media experts, 4) limited testing at SD Lab UNESA, and 5) revision of ICT-based levelling reading books from several aspects of study areas such as, content rules, consistency of picture captions in each competency and practitioner related to material and material weight. After going through several stages, ICT-based levelling reading books are recommended as one of the useful media to improve English vocabulary in inclusive elementary schools in Indonesia.

\section{A. Gathering Information}

Based on the need analysis in the field, there were many inclusive elementary students who experienced difficulties in English vocabulary mastery. Many inclusive elementary students were hampered by foreign language skills because they did not have enough vocabulary. This activity was carried out by the head of the research team.

\section{B. Product Design}

ICT-based levelling books are recognized as efficient tools for all grade 1 elementary students to boost their vocabulary. Software is operated on all computers and laptops based on Windows, Linux or Apple. It is not only can be applied on computers but also on all smart phones which have Android, Windows Mobile or Apple.

\section{Design Validation}

Design validation and products were validated by media experts

\section{Improved Design}

After product design, validation through discussions with experts and other experts were conducted to find out its weaknesses. The weakness was then tried to be reduced by improving the design.

\section{E. Product Trial}

ICT-based levelling reading book media product designs were directly tested after validation and revision. The initial stage trial was carried out using the media simulation. After being simulated, it was tested in a limited group. Tests were carried out to obtain information on whether ICT-based levelling reading book media were more effective and efficient compared to old teaching methods. In this case there were a Pre Test and a Post Test as shown below.

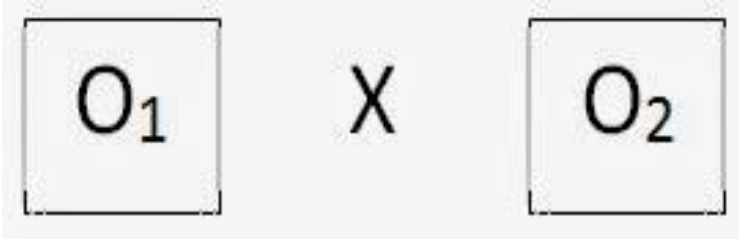

Fig. 1. Experimental Design (before after). O1 score before treatment and $\mathrm{O} 2$ score after treatment 


\section{RESULT AND DISCUSSION}

This research is a model development research. Borg and Gall (2003) simplify 10 steps in developing mini-learning into 3 main steps, namely (1) analysing the products to be developed, (2) developing the initial product, (3) expert validation and revision.

The purpose of the activity in phase one is the assessment and identification of problems and the facts that occur about the development of CAI-based Levelling Reading Books on inclusive students in grade 1 of elementary school. Activities carried out included (1) surveys and observations of needs analysis and analysis of constraints of classroom observations related to teaching materials. Students were interviewed related to the activities they did in the learning process. Then, the school optimized students' competencies by using CAI (Computer Assisted Instruction media). Obstacles analysis was reflected in the problems faced by students in improving their English language vocabulary, so that users can improve their vocabulary abilities.

As for what has been achieved from the first and second month, research activities were

- Preparation of research instruments for needs analysis and analysis of constraints on the difficulty of vocabulary mastery in Second Language Acquisition in second language mastery. Survey and observation of needs analysis, analysis of constraints of classroom observation related to English in inclusive elementary school and conducting interviews with teachers and students in elementary school were carried out at the beginning. Students were interviewed related to the activities they did in learning process, and efforts to optimize student competencies were made by using innovative learning media. Obstacle analysis was reflected in the problems faced by lecturers in improving their professional abilities, especially in developing student competencies in preparing media use.

- Drafting teaching materials for CAI-based Levelling Reading Books to improve vocabulary of inclusive students of elementary school in class 1

\section{A. Product Development Process}

After testing the product in a small group, there was an input, namely the CAI-based Levelling Reading Book media must be equipped with complete references to the standard that must be met by the child characteristic of $1^{\text {st }}$ graders inclusive elementary school. The results of the trial were used to improve the final product before Product Development Research is over.

Product revisions along with the progress and improvements that have been achieved to become the final report of the research activities from the third month until the end as followed:

- There has been media development from media experts and material experts related to the development of ICTbased Levelling Reading Books from the concept stage to the design stage. After that, gathering material that included materials that were in line with the ability of $1^{\text {st }}$ graders inclusive elementary school students.

- Design (prototype) of ICT-based Levelling Reading Book media has produced this media to produce a story line according to the characteristics of $1^{\text {st }}$ graders inclusive elementary school.

- The design was made into more detailed in terms of specifications about the program, style, appearance and material, and program needs. The specifications were made quite detailed so that in the next stage the Collecting Material became more and more directed using what was appropriate in the design stage. However, there were additions or changes in the display section or the application section which were omitted or added to this design.

- Eliminating various procedures for users of this Levelling Reading Book on the display so that it is easier for users to use this Computer Assisted Instruction based book.

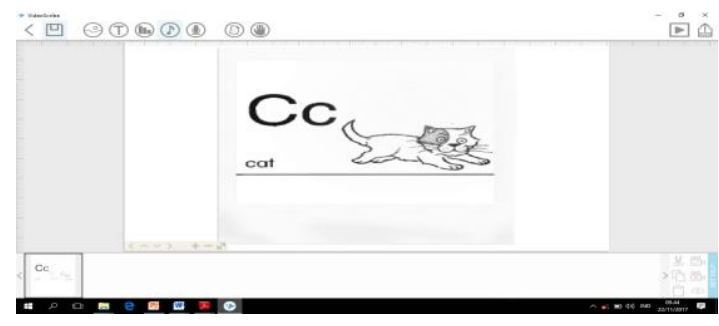

Fig. 2. Fig. 3. Images and Words will appear automatically when students click on the application

- When playing ICT-based Levelling Reading Book with just one click based on Sparcol, users can immediately get the benefits of it.

- Automatic sound will appear if the user changes in the ICT based Levelling Reading Book section for 1st graders inclusive elementary school students.

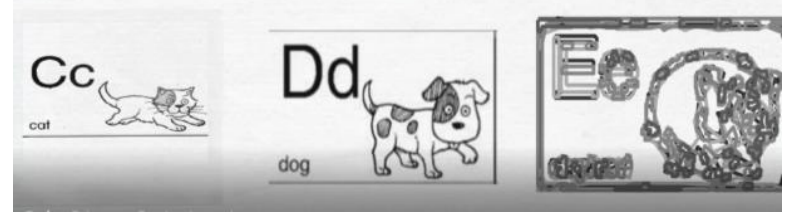

Fig. 3. Fig. 4. Display of ICT based Levelling Reading Books

- Images and pronunciation of automatic words (pronunciation) will appear if the user has used ICT based Levelling Reading Book.

\section{B. Product Experiment}

ICT-based Levelling Reading Books product designs were directly tested, after validation and revision. The initial stage trial was carried out using the media simulation. After being simulated, it was tested in a limited group. The test was carried 
out using the One Shot case study which only used Pre Test and Post Test. For the Pre Test score, a score of 65 was obtained while in the post test, it got 83 . This proves that the ICT-based levelling reading books are useful and effective in improving the vocabulary of the 1 st graders of inclusive students at elementary school.

\section{CONCLUSION}

ICT-based Levelling Reading Books have been programmed as tools to improve inclusive students' vocabulary in grade I of elementary school. It will run automatically if the user presses the play button so that each user can use the tool individually. ICT-based Levelling Reading Book can be operated on all computers and laptops using Windows, Linux or Apple. ICT-based Levelling Reading Books not only can be applied on computers but also on all smart phones with Android, Windows Mobile or Apple. The size of the media is not too big so it is not difficult for teachers or elementary school students to use because this ICT-based Levelling
Reading Books have been made based on the level of difficulties.

\section{REFERENCES}

[1] H. Mubarok, "Kontribusi USAID prioritas dalam menumbuhkankembangkan budaya literasi di sekolah SD/MI di Kabupaten Langkat," Analytica Islamica, vol 7, no. 1, pp. 47-59, Jun. 2018 .

[2] B. Warsita, Teknologi Pembelajaran Landasan \& Aplikasinya. Jakarta: Rineka Cipta, 2008.

[3] L. D. Prasojo, and R. Riyanto, Teknologi Informasi Pendidikan. Yogyakarta: Gava Media, 2011.

[4] H. B. Uno, and N. Lamatenggo, Teknologi Komunikasi dan Informasi Pembelajaran, 2nd ed. Jakarta: PT. Bumi Aksara, 2011

[5] M. Suyanto, Analisis \& Desain Aplikasi Multimedia untuk Pemasaran.Yogyakarta: Penerbit Andi, 2004.

[6] M. I. T. Munir, Pembelajaran Jarak Jauh Berbasis Teknologi Informasi dan Komunikasi. Bandung: Alfabeta, 2009.

[7] W.R Borg and M.D Gall, Educational Research: an Introduction, Fifth Edition. New York: Longman, 2003.

[8] Sugiyono, Metode Penelitian Pendidikan. Bandung: Alfabeta, 2008. 